\title{
Comparative Analysis of the Effect of Low-Dimensional Alumina Structures on Cell Lines L929 and Neuro-2a
}

\author{
A. N. Fomenko ${ }^{1, a)}$ and M. S. Korovin ${ }^{1, b)}$ \\ ${ }^{I}$ National Research Tomsk Polytechnic University, Lenin Avenue 30, Tomsk, 634050 Russia \\ a) Corresponding author: alserova@ispms.tsc.ru \\ b) msk@ispms.tsc.ru
}

\begin{abstract}
The paper presents the toxicity evaluation of nanostructures on the basis of alumina of different shape (nanofibers, nanoplates, nanosheets, nanosheet agglomerates) and with similar physical and chemical properties (particle size, specific surface area, phase composition, and zeta potential). The nanostructures were examined by transmission electron microscopy (TEM), scanning electron microscopy (SEM), X-ray diffraction (XRD), low-temperature nitrogen adsorption, and dynamic light scattering (DLS). The cytotoxicity of nanostructures was estimated using L929 fibroblast cells and Neuro-2a tumor cells. It has been found that the L929 cells are less subject to the influence of alumina nanoparticles than the Neuro-2a tumor cells. Probably, the differences in the proliferation activity of normal and tumor cells in contact with the synthesized nanostructures are due to a change in the $\mathrm{pH}$ of the cell microenvironment.
\end{abstract}

Keywords: alumina nanoparticles, low-dimensional structures, cell proliferation, cytotoxicity

\section{INTRODUCTION}

Today, due to the rapid development of nanotechnology more and more nanoparticles and materials on their basis are synthesized. The dimensions and unique properties of the particles make them widely applicable in the production of ceramics [1], adsorbents [2], catalysts [3], in food industry [4], and medicine [5-7]. This requires that nanomaterials be highly biosafe and raises serious concerns about their potential toxicity for human and environment [8]. The effects of nanomaterials on living cells, tissues, and organs are still not fully understood. Hence nanomaterials of different shapes and dimensions should be studied by visualization in the cell as well as by imaging and sensing for diagnostic and therapeutic purposes. One of the most important and demanded nanomaterials is alumina nanoparticles [9-11]. Recent studies have shown that the biological activity of alumina nanoparticles is due to their physical and chemical characteristics, such as shape, size, specific surface area, and other [12]. It has been found that alumina nanoparticles have higher toxicity compared to alumina microparticles [13], with $\gamma-\mathrm{Al}_{2} \mathrm{O}_{3}$ being more toxic than $\alpha-\mathrm{Al}_{2} \mathrm{O}_{3}$ [14]. An increase in the specific surface area also increases toxicity [15]. However, data on the influence of the nanoparticle shape are ambiguous. Many researches have shown that low-dimensional alumina structures are relatively safe compared to other metal oxide nanoparticles [16-19]. As yet, systematic studies into the relation between the cytotoxicity and morphology of nanoparticles have not been performed. Earlier we studied the effect of low-dimensional alumina structures of different morphology on the viability of L929 cell culture [20, 21]. It was suggested that one of the antitumor activity mechanisms of pseudoboehmite-based nanostructures can be the disturbance of the ionic balance in the cell microenvironment [22]. This suggestion was confirmed by the results reported in paper [23] that considers the adsorption of molecules from the intracellular environment to the surface of layered double hydroxide (LDH). This paper focuses on a comparative analysis of how the morphology of low-dimensional alumina nanostructures affects the normal cell line L929 and tumor cell line Neuro-2a. These cell lines were chosen because they are highly sensitive to external influences.

Physics of Cancer: Interdisciplinary Problems and Clinical Applications (PC'16) AIP Conf. Proc. 1760, 020015-1-020015-6; doi: 10.1063/1.4960234 Published by AIP Publishing. 978-0-7354-1418-1/\$30.00 


\section{MATERIALS AND INVESTIGATION PROCEDURES}

The experiments were conducted on 4 types of low-dimensional alumina structures: nanosheet agglomerates $(0.5-2 \mu \mathrm{m})$, nanofibers $(200-400 \mathrm{~nm})$, nanosheets $(100-500 \mathrm{~nm})$, and nanoplates $(40-100 \mathrm{~nm})$. The samples for the investigation were produced and synthesized in the Laboratory of Physics and Chemistry of Highly Dispersed Materials of ISPMS SB RAS (Russia, Tomsk). The samples were prepared as follows:

1. Preparation of alumina nanosheet agglomerates

Alumina nanosheet agglomerates were synthesized in a simple reaction of Al/AlN conversion in water [24]. Al/AlN nanoparticles were synthesized by electric explosion of alumina wire in nitrogen atmosphere [25, 26]. 0.5 g of precursor was added to $50 \mathrm{ml}$ of deionized water. Then, the suspension was incubated in waterbath for 1 hour at temperature $60^{\circ} \mathrm{C}$. The reaction products were centrifuged, rinsed several times with deionized water, and dried at $100^{\circ} \mathrm{C}$ for 4 hours.

2. Preparation of alumina nanofibers

Alumina nanofibers were synthesized by oxidizing an alumina plate according to the technique described elsewhere [16]. For this purpose, the passivating oxide film was removed from the alumina plate ( $99.9 \%$ purity) by amalgamation. The prepared plate was placed into a climate chamber at temperature $30^{\circ} \mathrm{C}$ and $80 \%$ humidity. The produced sample of nanofibers was detached from the plate and dried at $100^{\circ} \mathrm{C}$ for 4 hours.

3. Preparation of alumina nanoplates

Alumina nanoplates were synthesized by hydrothermal treatment of the suspension of alumina nanosheet agglomerates in a mother solution. The hydrothermal synthesis reactor was heated in a drying chamber at temperature $150^{\circ} \mathrm{C}$ for $60 \mathrm{~min}$. Then, the suspension was filtered and dried at $100^{\circ} \mathrm{C}$ for 4 hours.

4. Preparation of alumina nanosheets

Alumina nanosheets were synthesized using the sol-gel method. $10 \mathrm{~g}$ of alumina nitrate $\left(\mathrm{Al}\left(\mathrm{NO}_{3}\right)_{3} \times 9 \mathrm{H}_{2} \mathrm{O}\right.$ were added to reverse osmosis water $(100 \mathrm{~mL})$. Then, $\mathrm{NaOH}$ solution was added dropwise in $2 \mathrm{M}$ drops at room temperature with constant agitation to achieve $\mathrm{pH} 11$. The obtained mixture was kept for 12 hours, after which the precipitate was separated, water rinsed to neutral $\mathrm{pH}$, and dried at $80^{\circ} \mathrm{C}$ for 12 hours.

\section{Description of Low-Dimensional Alumina Structures}

The morphology of low-dimensional alumina structures was examined by transmission electron microscopy (JEOL-2100, JEM, Japan, worked at $200 \mathrm{kV}$ ) and X-ray diffraction (XRD-6000, $\mathrm{CuK}_{\alpha}$ irradiation, wavelength = $1.54056 \AA$ ). The specific surface was measured by nitrogen adsorption on a device Sorbometer M (Catakon, Russia). The specific surface area was calculated by the BET method in the relative pressure range $0.05-0.35$. The zeta potential was determined by the electrophoretic mobility of particles with the front detection by dynamic light scattering on a Zetasizer (DLS, Zetasizer Nano ZSP (Malvern Instruments Ltd, UK)). pH was measured using a pHmeter Multitest IPL-103 (Semico, Russia).

\section{Cell Cultures and Investigation of Cytotoxic Effect of Alumina Nanoparticles}

Mouse fibroblasts (L929) and mouse neuroblastoma cells (Neuro-2a) were provided by the State Research Center of Virology and Biotechnology VECTOR (Russia). The cell lines were cultivated in Eagle's MEM cell culture medium (Lonza, Switzerland) containing 10\% fetal bovine serum (FBS, Hyclone, US) and 5\% penicillinstreptomycin-glutamine in dishes of area $75 \mathrm{~cm}^{2}$ at $37^{\circ} \mathrm{C}$ in a $5 \% \mathrm{CO} 2 / 95 \%$ air humid atmosphere (Sanyo, Japan). Before adding the nanostructures to the cell systems, the synthesized samples (weighing $0.08 \mathrm{~g}$ ) were suspended in $20 \mathrm{~mL}$ nutrient medium. Each cell culture was inoculated in 24-well cell culture dishes (total volume $2 \mathrm{~mL}$ ) in an amount of 160000 cells/well. $1 \mathrm{~mL}$ suspension of the studied low-dimensional structures was inoculated in each well. The cells were incubated for 24,48 , and 72 hours. Then, the cells were counted on a hemocytometer by using trypan blue vital staining. The control cell culture was the initial culture that was not in contact with the lowdimensional structures. The statistical processing of the results was carried out using parametric methods at the significance level $p \leq 0.05$. 


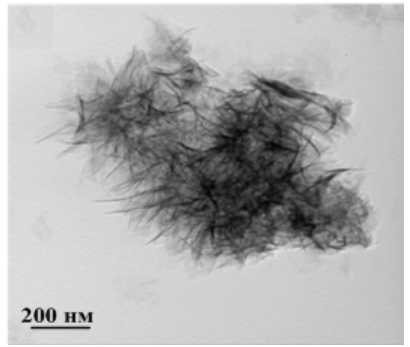

(a)

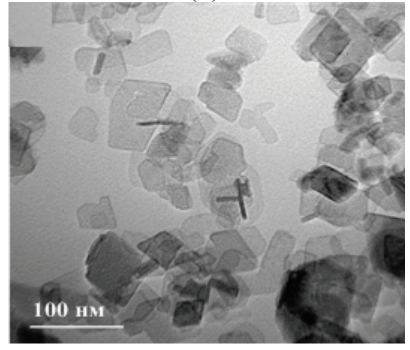

(c)

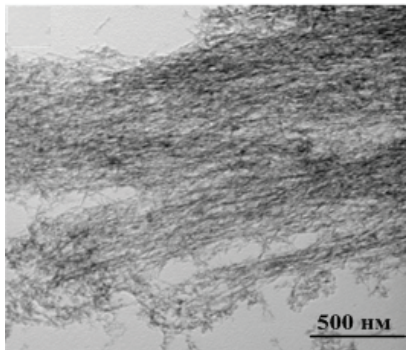

(b)

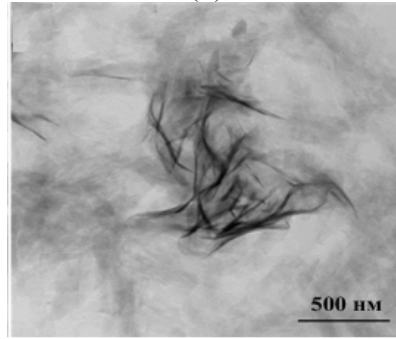

(d)

FIGURE 1. TEM images of nanostructures with different morphology: (a) nanosheet agglomerates,

(b) nanofibers, c) nanoplates, (d) nanosheets

\section{RESULTS AND DISCUSSION}

The interaction of $\mathrm{Al} / \mathrm{AlN}$ nanopowder with water results in the formation of alumina nanosheet agglomerates consisting of individual sheets of thickness 2-5 nm and planar size about 150-300 nm (Fig. 1a). As a result of oxidation of the amalgamated alumina plate in humid air, alumina nanofibers of diameter from 10 to $20 \mathrm{~nm}$ and length up to several micrometers are formed (Fig. 1b). The exposure of alumina nanosheet agglomerates in hydrothermal conditions at $200^{\circ} \mathrm{C}$ for $6 \mathrm{~h}$ causes the formation of irregularly shaped alumina plates of size 20 $100 \mathrm{~nm}$ and thickness $4-15 \mathrm{~nm}$ (Fig. 1c).

The low-dimensional structures synthesized by the sol-gel method represent folded nanosheets of size 50$200 \mathrm{~nm}$ and thickness about 1-5 nm (Fig. 1d). The physical and chemical characteristics of all synthesized lowdimensional structures are close in value and given in Table 1.

As was discussed elsewhere [27-29], the cytotoxic effect of nanomaterials on cells, organs, and the human body has not yet been properly understood. Moreover, complex data on the cytotoxicity of alumina nanoplates, nanofibers, nanosheets, and nanosheet agglomerates are more deficient compared to the data for other materials consisting of gold, silver, or carbon. L929 and Neuro-2a are among the cells most widely used in studying the toxic effect of nanostructures. These cells are as a rule more sensitive to cytotoxic compounds because they have higher ability of endocytosis [30].

Neuro-2a cells were more subject to the influence of alumina nanostructures than L929 cells (Fig. 2). Investigations showed ( $p<0.05$, Fig. $2 \mathrm{a})$ that the application of low-dimensional structures ( $24 \mathrm{~h}$ of contact) causes a $5-8 \%$ viability reduction of L929 cells.

TABLE 1. Physical and chemical characteristics of low-dimensional structures

\begin{tabular}{lccc}
\hline \multicolumn{1}{c}{ Sample } & Specific surface area, $\mathbf{~ m}^{\mathbf{2}} \mathbf{g}$ & Phase composition & $\boldsymbol{\zeta}, \mathbf{m V}$ \\
\hline Nanosheet agglomerates & $268 \pm 5$ & pseudoboehmite & $39 \pm 3$ \\
\hline Nanofibers & $254 \pm 5$ & $\gamma-\mathrm{Al}_{2} \mathrm{O}_{3}[21]$ & $41 \pm 2$ \\
\hline Nameplates & $81 \pm 10$ & Boehmite & $36 \pm 5$ \\
\hline Nanosheets & $226 \pm 4$ & Pseudoboehmite & $40 \pm 4$ \\
\hline
\end{tabular}




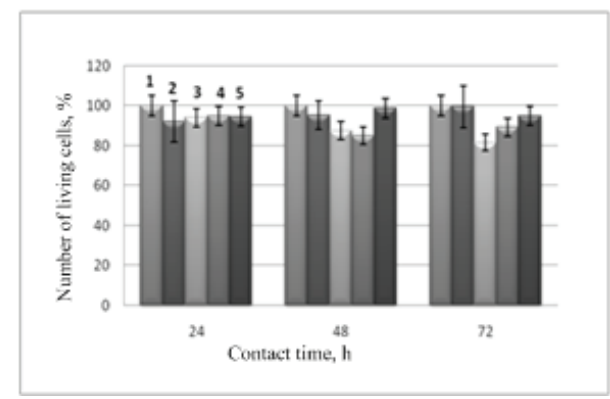

(a)

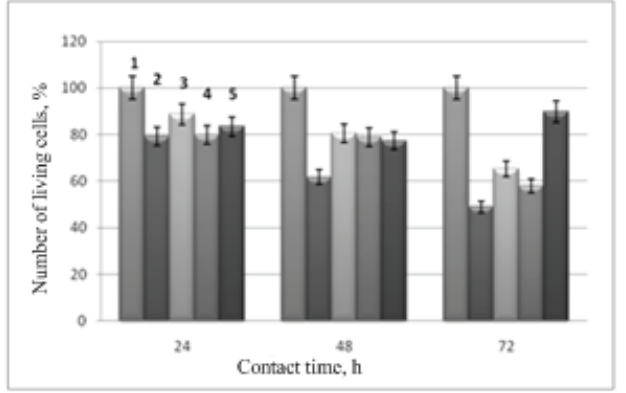

(b)

FIGURE 2. Effect of low-dimensional structures on cell line L929 (a) and cell line Neuro-2a (b): 1 - control, 2-nanosheet agglomerates, 3-nanofibers, 4-nanosheets, 5-nanofibers

After $48 \mathrm{~h}$ of contact nanosheet agglomerates and nanoplates had no pronounced negative effect on the cells (2$5 \%$ decrease in proliferation), and after the application of nanofibers and nanosheets the number of viable cells reduced by $13 \%$ and $19 \%$, respectively. After $72 \mathrm{~h}$ of contact nanosheet agglomerates and nanoplates, as compared to the control cell culture, had almost no negative effect on the cell viability (1-3\%). After 72 hours of contact with nanofibers and nanosheets the cell growth rate decreased by $16 \%$ and $20 \%$, respectively.

The conducted experiments revealed that the inhibition of the viability of Neuro-2a tumor cells (Fig. 2b) began after $24 \mathrm{~h}$ of contact with the samples. After $48 \mathrm{~h}$ the cell viability reduction was higher for nanosheet agglomerates and is maximum after $72 \mathrm{~h}$ of contact $(50 \%)$. Nanoplates also inhibited the cell viability, namely, for line Neuro-2a the number of cells after $48 \mathrm{~h}$ reduced by $25 \%$, while after $72 \mathrm{~h}$ the number of viable cells increased. The toxicity of low-dimensional alumina structures increased in the series nanoplates-nanofibers-nanosheets-nanosheet agglomerates (Fig. 2).

The process of determining the localization of alumina nanoparticles is cumbersome. Optical microscopy images showed that many aggregates of alumina nanostructures (Fig. 3) were localized on the cell surface.

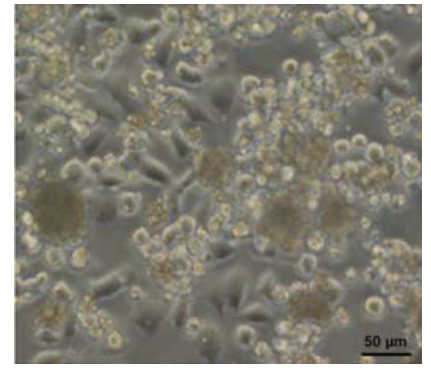

(a)

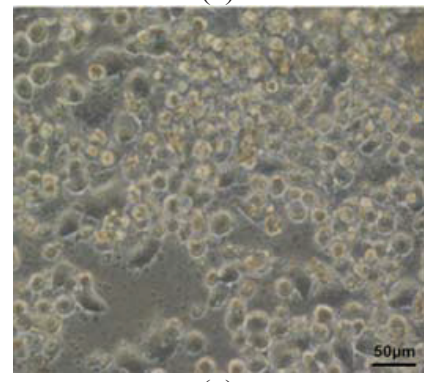

(c)

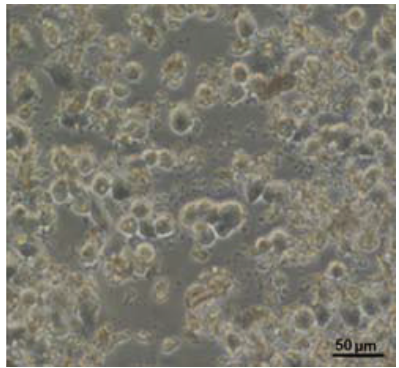

(b)

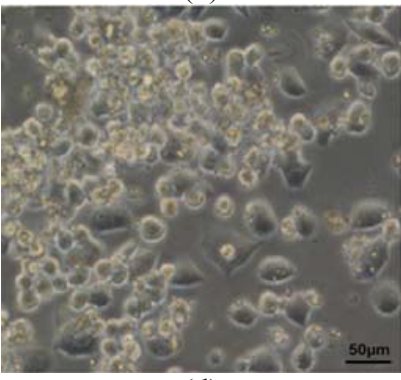

(d)

FIGURE 3. Optical microscopy images of alumina nanostructures on Neuro-2a cell line: (a) nanosheet agglomerates, (b) nanofibers, (c) nanosheets, (d) nanoplates 
Figure 3 depicts the distribution of alumina nanoparticles on the cell surface in a well of the 24 well plate: nanosheet agglomerates (Fig. 3a), nanofibers (Fig. 3b), nanosheets (Fig. 3c), and nanoplates (Fig. 3d). Aggregates of alumina nanostructures were mainly concentrated in the central part of the culture plate or on cells (Figs. 3a, 3c, 3d). Similar results of alumina nanostructure localization were obtained after incubation with L929 fibroblasts (data are not displayed). Thus, the synthesized nanostructures in the medium aggregate and cannot penetrate into the cell [3134]. Their toxic effect is first of all related to changes in the cell microenvironment and interaction with the cell surface.

Since we observe a different influence of nanostructures on normal and tumor cells (Fig. 2), it can be surmised that the shape and composition do not affect the cell viability. A more pronounced tumor cell inhibition can be either due to the lack of their proper nutrition because of amino acid adsorption from the nutrient medium (tumor cells need more energy to live) or due to a change in the ionic state of the cell microenvironment. A complex characteristic that reflects the ionic state of biological media, including intracellular ones, is the $\mathrm{pH}$ value [35-36]. For example, as a consequence of the changed metabolism tumor cells create an acidic environment that has a lower $\mathrm{pH}$ value compared to normal cells [37]. Hence an increase in the $\mathrm{pH}$ of the tumor cell microenvironment exerts a negative effect on their viability.

Additional experiments revealed that the synthesized nanostructures increase the $\mathrm{pH}$ of the EMEM cell culture meidum by more than 1 unit (Fig. 4).

Nanosheet aglomerates, nanosheets and nanofibers increase the $\mathrm{pH}$ of the medium up to $\sim 8.6$ for 72 hours. Nanoplates increase the $\mathrm{pH}$ up to $\sim 8.4$. Probably, the tumor cell growth after 72 hours of contact with nanoplates is explained by the slight increase in the $\mathrm{pH}$ of the medium (Fig. 2b).

Thus, differences in the proliferation of normal and tumor cells can be associated with the increase in the $\mathrm{pH}$ of the cell microenvironment. The tendency is especially observed for tumor cells: a less inhibition of their proliferation after 72 hours of contact is observed for nanoplates that are less prone to increase the $\mathrm{pH}$ of the medium.

\section{CONCLUSION}

It was found in laboratory conditions on cell lines L929 and Neuro-2a that all the studied low-dimensional alumina structures exhibit a different degree of toxicity. The synthesized nanostructures exert a lower effect on the proliferation activity of L929 cells compared to Neuro-2a cells. Nanostructures were found to strongly aggregate in the nutrient medium, which reduces their ability of endocytosis. However, it is impossible on the current stage of research to exclude the inhibition of tumor cell proliferation due to endocytosis.

It was shown that the synthesized nanostructures increase the $\mathrm{pH}$ of the cell culture medium. Hence the difference in the proliferation activity of normal and tumor cells most probably results from a change in the $\mathrm{pH}$ of the cell microenvironment.

A comparative analysis revealed that Neuro-2a tumor cells are more subject to the influence of low-dimensional alumina structures than L929 cells. The application of nanostructures on the basis of alumina oxyhydroxides is a promising way of affecting the intracellular environment to suppress tumor cell proliferation.

\section{ACKNOWLEDGMENTS}

The work was carried out at the financial support of the Russian Scientific Foundation (Grant No. 14-23-00096).

The study reported in this article was conducted according to accepted ethical guidelines involving research in humans and/or animals and was approved by an appropriate institution or national research organization. The study is compliant with the ethical standards as currently outlined in the Declaration of Helsinki. All individual participants discussed in this study, or for whom any identifying information or image has been presented, have freely given their informed written consent for such information and/or image to be included in the published article.

\section{REFERENCES}

1. M. Schwentenwein and J. Homa, Int. J. Appl. Ceram. Tech. 12, 1-7 (2015).

2. E. Mohammadifar, F. Shemirani, B. Majidi, and E. Ezoddin, Desalin. Water Treatm. 54, 758-768 (2015).

3. W. Wu, Z. Wan, W. Chen, H. Yang, and D. K. Dongke, Adv. Powd. Tech. 25, 1220-1226 (2014).

4. Z. Zhang, Y. Ma, Q. Wang, A. Chen, Z.Y. Pan, and G.K. Li, J. Chromatography A 1290, 27-35 (2013). 
5. G. Mikhaylov, D. Klimpel, N. Schaschke, U. Mikac, M. Vizovisek, M. Fonovic, V. Turk, B. Turk, and O. Vasiljeva, Angew. Chem. Int. Ed. 53(38), 10077-10081 (2014).

6. G. Mikhaylov, U. Mikac, A. A. Magaeva, V. I. Itin, E. P. Naiden, I. Psakhye, and M. Bogyo, Nature Nanotechnology 6(9), 594-602 (2011).

7. N. V. Svarovskaya, A. V. Berenda, O. V. Bakina, E. A. Glazkova, A. S. Lozhkomoev, E. G. Khorobraya, V. V. Domashenko, M. I. Lerner, and A. N. Fomenko, Progr. Nat. Sci. Mater. Int. 25(1), 1-5 (2015).

8. O. V. Bakina, N. V. Svarovskaya, E. A. Glazkova, A. S. Lozhkomoev, E. G. Khorobraya, and M. I. Lerner, Adv. Powder Technol. 26(6), 1512-1519 (2015).

9. A. S. Lozhkomoev, E. A. Glazkova, N. V. Svarovskaya, O. V. Bakina, S. O. Kazantsev, and M. I. Lerner, AIP Conf. Proc. 1683, 020128 (2015).

10. A. S. Lozhkomoev, E. A. Glazkova, N. V. Svarovskaya, O. V. Bakina, S. O. Kazantsev, and M. I. Lerner, AIP Conf. Proc. 1683, 020127 (2015).

11. O. V. Bakina, E. A. Glazkova, N. V. Svarovskaya, A. S. Lozhkomoev, E. G. Khorobraya, and S. G. Psakhie, AIP Conf. Proc. 1623, 35 (2014).

12. L. Yang and D. J. Watts, Toxicol. Lett. 158, 122-132 (2005).

13. LQ. L. Zhang, L. Xu, J. Wang, E. Sabbioni, L. Y. Piao, M. Di Gioacchino, and Q. Niu, J. Biol. Regulators Homeostatic Agents 27, 365-375 (2013).

14. S. Pakrashi, D. Kumar, V. Iswarya, M. Bhuvaneshwari, N. Chandrasekaran, and A. Mukherjee, Bioproc. Biosyst. Eng. 37, 2415-2423 (2014).

15. I. L. Hsiao and Y. J. Huang, Sci. Total Envir. 409, 1219-1228 (2011).

16. J. L. Vignes, C. Frappart, T. Di Costanzo, J. C. Rouchaud, L. Mazerolles, and D. Michel, J. Mater. Sci. 43, 1234-1240 (2008).

17. D. Khang, P. Liu-Snyder, R. Pareta, J. Lu, and T. J. Webster, Acta Biomater. 5, 1425-1432 (2009).

18. G. Karunakaran, R. Suriyaprabha, V. Rajendran, and N. Kannan, IET Nanobiotechnology 1, 27-34 (2015).

19. S. Katsamakis, D. E. Slot, L. M. Van der Sluis, and F. Van der Weijden, J. Clin. Periodontol. 40, 334-344 (2013).

20. A. N. Fomenko, M. S. Korovin, O. V. Bakina, S. O. Kazantsev, E. A. Glazkova, N. V. Svarovskaya, and A. S. Lozhkomoev, AIP Conf. Proc. 1683, 020054 (2015).

21. S. O. Kazantsev, A. N. Fomenko, M. S. Korovin, E. A. Glazkova, A. S. Lozhkomoev, M. I. Lerner, and S. G. Psakhie, AIP Conf. Proc. 1683, 020080 (2015).

22. A. S. Lozhkomoev, M. I. Lerner, A. A. Tsukanov, S. O. Kazantsev, O. V. Bakina, and S. G. Psakhie, Fiz. Mezomekh. 19(2), 24-31 (2016).

23. A. A. Tsukanov and S. G. Psakhie, Sci. Rep. 6, 19986 (2016).

24. N. V. Svarovskaya, O. V. Bakina, E. A. Glazkova, M. I. Lerner, and S. G. Psakh'e, Russ. J. Phys. Chem. A 84(9), 1566-1569 (2010).

25. M. I. Lerner, E. A. Glazkova, A. S. Lozhkomoev, N. V. Svarovskaya, O. V. Bakina, A. V. Pervikov, and S. G. Psakhie, Powder Technology 295, 307-314 (2016).

26. S. G. Psakhie, K. P. Zolnikov, D. S. Kryzhevich, A. V. Abdrashitov, and M. I. Lerner, Phys. Mesomech. 13(3), 184-188 (2010).

27. N. Lewinski, V. Colvin, and R. Drezek, Small 4, 26-49 (2008).

28. A. Kumar and A. Dhawan, Arch. Toxicol. 87, 1883-1900 (2013).

29. E. Frohlich, Curr. Drug. Metab. 14, 976-988 (2013).

30. S. Zhang, J. Li, G. Lykotrafitis, G. Bao, and S. Suresh, Adv. Mater. 21, 419-424 (2009).

31. W. Jiang, B. Y. S. Kim, J. T. Rutka, and W. C. W. Chan, Nature Nanotech. 3, 145-150 (2008).

32. A. J. Wagner, C. A. Bleckmann, R. C. Murdock, A. M. Schrand, J. J. Schlager, and S. M. Hussain, J. Phys. Chem. B 111, 7353-7359 (2007).

33. J. T. Kwon, G. B. Seo, E. Jo, M. Lee, H. M. Kim, I. Shim, B. W. Lee, B. I. Yoon, P. Kim, and K. Choi, Toxicol. Res. 29, 181-185 (2013).

34. N. Puvvada, S. Rajput, B. N. P. Kumar, S. Sarkar, S. Konar, K. R. Brunt, R. R. Rao, A. Mazumdar, S. K. Das, R. Basu, P. B. Fisher, M. Mandal, and A. Pathak, Sci. Rep. 5, 11760 (2015).

35. I. F. Robey, B. K. Baggett, N. D. Kirkpatrick, D. J. Roe, J. Dosescu, B. F. Sloane, A. I. Hashim, D. L. Morse, N. Raghunand, R. A. Gatenby, and R. J. Gillies, Cancer Research 69(6), 2260-2268 (2009).

36. D. M. Prescott, H. C. Charles, J. M. Poulson R. L. Page, D. E. Thrall, Z. Vujaskovic, and M. W. Dewhirst, Clinical Cancer Res. 6(6), 2501-2505 (2000).

37. R. A. Cardone, V. Casavola, and S. J. Reshkin, Nat. Rev. Cancer 5(10), 786-795 (2005). 